\title{
Optimization Extraction of Xylocarpus granatum Stem as Antioxidant and Antiglycation
}

\author{
Eka Winarni Sapitri', Irmanida Batubara ${ }^{1,2 *}$, Utami Dyah Syafitri3 \\ 'Department of Chemistry, Bogor Agricultural University, Bogor, Indonesia \\ ${ }^{2}$ Tropical Biopharmaca Research Center, Bogor Agricultural University, Bogor, Indonesia \\ ${ }^{3}$ Department of Statistics Bogor Agricultural University, Bogor, Indonesia
}

\section{ARTICLE INFO}

Article history:

Received August 8, 2018

Received in revised form January 4, 2019

Accepted January 10, 2019

KEYWORDS:

ABTS,

antiglycation,

DPPH,

stem of Xylocarous granatum

\begin{abstract}
Xylocarpus granatum is an Indonesian plant that has bioactive compounds such as phenolic and has high antioxidant activity. The aim of this research was to determine the optimum maceration condition for $X$. granatum stem as antioxidant and antiglycation. The optimum conditions of maceration were affected by the extraction variables (concentration, sample/solvent ratio, extraction time), and could be evaluated by using surface response method. The optimum condition of maceration is predicted to be achieved when the ethanol concentration as solvent is $52.25 \%$, the extraction time is 15.92 hours, sample/solvent ratio is $1 \mathrm{~g} / 9 \mathrm{ml}$ with the responds of yield, total phenol content, flavonoid, inhibition for 2,2'-diphenylpicryl hydrazyl, inhibition capacity of 2,2'-azino-bis(3-ethylbenzothiazoline-6-sulfonic acid), and inhibition antiglycation were $12.81 \%, 1.95 \mathrm{mg}$ of gallic acid/g extract, $62.33 \mu \mathrm{g}$ quercetin/g extract, $41.11 \%, 0.71 \mathrm{TEAC}$, and $112.33 \%$, respectively. Optimization extraction conditions shows that the extraction variables have significant effect on responds so it can reduce the extraction time, produce high bioactive constituents, and reduce the production cost.
\end{abstract}

\section{Introduction}

Indonesia is a tropical country that has a lot of UV exposure from sunlight. This sunlight can accelerate free radicals' production. Free radicals can accelerate skin aging and increase the activity of the tyrosinase enzyme which is responsible for melanogenesis or hyperpigmentation (Batubara and Adfa 2013). Halliwell (2001) in Yagi et al. (2013) reported that free radicals play a role in the formation of advanced glycation end products (AGEs). Glycation is a nonenzymatic reaction between reducing sugars and amino groups of proteins, nucleic acids, or phospholipids to form AGEs (Yeh et al. 2017). The effects of AGEs, recent studies have also addressed on many chronic diseases and aging-related disease in clinical practice (Rabbani et al. 2016). Antiglycation has been considered as an effective strategy to slow down human aging and disease development (Yeh et al. 2017).

Antioxidants can be used to prevent skin aging (Thornfeldt and Bourne 2010). One of antioxidant substances is polyphenol. Polyphenols can inhibit the

\footnotetext{
* Corresponding Author

E-mail Address: ime@apps.ipb.ac.id
}

biosynthesis of AGEs through antioxidant properties, metal-chelating ability, protein interaction, and blocking the receptor for advanced glycation end products (AGEs) (Chen et al. 2006). Plants can be used as a source of natural antioxidants (Bernatoniene et al. 2011). Xylocarpus granatum is a mangrove plant which has phenolic bioactive compounds, alkaloids, steroids (Kopkol et al. 1990; Bandaranayake 2002), and triterpenoids (Gazali et al. 2014). According to Batubara et al. (2010), the stem part of X. granatum can be a source of antioxidants and whitening agent. In addition to the stem, seed and fruit peel of $X$. granatum can be used as a source of antioxidants (Zamani et al. 2015), but stem part has the highest antioxidant activity and tyrosinase inhibitors (Darusman et al. 2011; Gazali et al. 2014; Zamani et al. 2015).

Extraction optimization was carried out to obtain the optimum extraction conditions. Extraction can be influence by several factor such as extraction time, variation in solvent concentration, and sample ratio with solvent. Determination of the optimum extraction conditions is carried out using the surface response method. Responses were reviewed based on the acquisition of total phenol content, total 
flavonoids, antioxidant activity, and antiglycation activity of $X$. granatum stem. The aim of this research was to determine the optimum maceration condition for X. granatum stem as antioxidant and antiglycation.

\section{Materials and Methods}

\subsection{Plant Materials}

$X$. granatum stem from Togean, Central Sulawesi.

\subsection{Chemicals and Instruments}

The chemical used are 2,2'-diphenylpicryl hydrazyl (DPPH), ethanol, methanol, bovine serum albumin (BSA), 2,2'-azinobis(3-ethylbenzothiazoline-6-sulfonic acid) (ABTS), glucose, fructose, Folin-Ciocalteu's reagent, gallic acid, ascorbate acid, and quercetin. The instrument used are ELISA plate well reader (Merk Biotek Epoc Spektro UV-Vis), and fluorometer (FluoroStar BMG Labtech).

\subsection{Design of Experiments for $X$. granatum's Extraction}

The Central Composite Design (CCD) method (Table 1) was used in order to optimize seven different response variable; yields, phenolic content, flavonoid content, antioxidant (DPPH and ABTS), and antiglycation.

\subsection{Total Phenolic Content (TPC)}

Total phenolic content was determined according to the previous method (Premakumara et al. 2013). Briefly, $20 \mu \mathrm{l}$ extract or standard solution (gallic acid)

Table 1. Design of experiments central composite design

\begin{tabular}{rccc}
\hline Run order & $\begin{array}{c}\text { Ethanol } \\
\text { concentration } \\
(\%)\end{array}$ & $\begin{array}{c}\text { Extraction } \\
\text { time (hours) }\end{array}$ & $\begin{array}{c}\text { Ratio } \\
\text { sample:solvent } \\
\text { (g:ml) }\end{array}$ \\
\hline 1 & 0 & 24 & $1: 3$ \\
2 & 0 & 16 & $1: 6$ \\
3 & 40 & 16 & $1: 3$ \\
4 & 40 & 8 & $1: 6$ \\
5 & 80 & 8 & $1: 3$ \\
6 & 40 & 16 & $1: 6$ \\
7 & 40 & 16 & $1: 6$ \\
8 & 40 & 16 & $1: 6$ \\
9 & 80 & 8 & $1: 9$ \\
10 & 40 & 16 & $1: 6$ \\
11 & 40 & 16 & $1: 6$ \\
12 & 40 & 16 & $1: 6$ \\
13 & 0 & 8 & $1: 9$ \\
14 & 80 & 16 & $1: 6$ \\
15 & 40 & 24 & $1: 6$ \\
16 & 40 & 16 & $1: 9$ \\
17 & 0 & 24 & $1: 9$ \\
18 & 0 & 8 & $1: 3$ \\
19 & 80 & 24 & $1: 3$ \\
20 & 80 & 24 & $1: 9$ \\
\hline
\end{tabular}

of different concentrations (0-100 mg/l) was added $110 \mu \mathrm{l}$ Folin-Ciocalteu's reagent to the well plate. Sodium carbonate $(70 \mu \mathrm{l})$ was added to the mixture. After incubation at room temperature for 30 minutes, the absorbance was measured at $765 \mathrm{~nm}$ using a ELISA reader. Total phenolic content of the samples were determined by plotting the absorbance data of sample into calibration curve of gallic acid. The results were then expressed as gallic acid equivalents (GAE) (\% (w/w))of extract.

\subsection{Total Flavonoid Content (TFC)}

Total flavonoid was determined as described by Lee et al. (2011). Extract or standard solution $(10 \mu \mathrm{l})$ was added into the well plate containing $60 \mu \mathrm{l}$ methanol, $10 \mu \mathrm{l} \mathrm{AlCl}{ }_{3} 10 \%, 10 \mu \mathrm{CH}_{3} \mathrm{COONa}_{1}$ $\mathrm{M}$, and $120 \mu \mathrm{l}$ water. The mixture was incubated at room temperature for 30 minutes, the absorbance was measured at $415 \mathrm{~nm}$. Quercetin was used as a standard solution. The results were expressed as quercetin equivalent $(\%(w / w))$ of the extract.

\subsection{Antioxidant Activities}

DPPH radical scavenging activity. The experiment was conducted as described by Batubara et al. (2015) with some modifications. DPPH solution $(100 \mu \mathrm{l})$ $(125 \mu \mathrm{m})$ was reacted with $100 \mu \mathrm{l}$ sample (500, $250,125,62.5$, and $31.25 \mu \mathrm{g} / \mathrm{ml}$ ). The mixture was then incubated for 30 minutes. After incubation, the absorbance was read at $517 \mathrm{~nm}$. Ascorbic acid was used as positive control, while ethanol was used as solvent and negative control.

ABTS. The experiment was conducted as described by Ree et al. 1999 with some modifications. ABTS solution $10 \mathrm{ml}(7 \mathrm{mM})$ was oxidized by $5 \mathrm{ml}$ potassium peroxide sulfate $(2.55 \mathrm{mmol} / \mathrm{l})$ for 16 hours. Further, about $180 \mu \mathrm{l}$ ABTS radical was reacted with $20 \mu \mathrm{l}$ sample and incubated for 15 minutes at microplate 96 well. The absorbance was measured at $734 \mathrm{~nm}$. The results were expressed as Trolox Equivalents Antioxidant Capacity (TEAC) \% w/w.

\subsection{Antiglycation}

Antiglycation was measured according to the method described by Povichit et al. (2010) with a slight modification. The reaction consisted of $80 \mu \mathrm{BSA}$ (20 $\mathrm{mg} / \mathrm{ml}), 40 \mu$ glucose $(235 \mathrm{mM}), 40 \mu$ fructose (235 $\mathrm{mM}$ ), and $80 \mu \mathrm{l}$ of sample or positive control in 200 $\mu$ phosphate buffer $0.2 \mathrm{M}(\mathrm{pH} 7.4)$. The solution was incubated for 40 hours at $60^{\circ} \mathrm{C}$, and then the excitation fluorescence intensity was measured at $370 \mathrm{~nm}$ and the emission at $440 \mathrm{~nm}$. Aminoguanidine was applied as a positive control. Sample and positive control corrected 
solution were prepared same like sample but water used to replace the sample or positive control. Antiglycation activity was measured by using the following equation:

$$
\% \text { inhibition }=\left[1-\frac{C-D}{A-B}\right] \times 100 \%
$$

where,
A
B :fluoresce
:fluorescence intensity of control solution
C :fluorescene intensity of sample solution
D :fluorescene intensity of sample corrected solution

\section{Results}

The yield of extracts from the $X$. granatum stem of 20 run order ranges from $4.33 \%$ to $12.88 \%$ (Table 2 ). The etanol 80\% extract, extraction time 24 hour, and ratio sample:solvent (1:9) gave the highest yield. This indicates that stem contained semi-polar compound rather than more polar compounds. The content of the extracts will directly correlate with the activity. Different constituents will give different activities. Total phenolic of 20 run order extracts and its extract were expressed as miligram gallic acid equivalent/gram extract. The amount of total phenolic contents ranged from 0.57 to $1.89 \mathrm{mg}$ gallic acid/g extract (Table 2 ). The ethanol $40 \%$, extraction time 16 hour, and ratio sampel:solvent

Table 2. Extraction yield, total phenolic, and total flavonoid contents of $X$. granatum stem extracts

\begin{tabular}{|c|c|c|c|}
\hline $\begin{array}{l}\text { Run } \\
\text { order }\end{array}$ & $\begin{array}{c}\text { Extraction } \\
\text { yield (\%) }\end{array}$ & $\begin{array}{l}\text { Total phenolic } \\
\text { (mg gallic acid/g } \\
\text { extract) }\end{array}$ & $\begin{array}{l}\text { Total flavonoid } \\
\text { ( } \mu \text { g quecetin } / g \\
\text { extract) }\end{array}$ \\
\hline 1 & $4.33 \pm 1.26^{\mathrm{j}}$ & $0.30 \pm 0.01^{\mathrm{k}}$ & $23.36 \pm 0.74^{g}$ \\
\hline 2 & $5.49 \pm 1.04^{\text {hij }}$ & $0.20 \pm 0.02^{1}$ & $25.86 \pm 3.09^{g}$ \\
\hline 3 & $6.76 \pm 1.81^{\text {fghij }}$ & $1.10 \pm 0.02^{g}$ & $27.11 \pm 10.98^{\text {fg }}$ \\
\hline 4 & $6.90 \pm 1.03^{\text {fghij }}$ & $1.43 \pm 0.03^{\mathrm{d}}$ & $23.66 \pm 1.51^{\mathrm{g}}$ \\
\hline 5 & $4.84 \pm 3.31^{\mathrm{ij}}$ & $0.84 \pm 0.03^{\mathrm{h}}$ & $25.15 \pm 2.58^{g}$ \\
\hline 6 & $10.33 \pm 2.24^{\mathrm{abcd}}$ & $1.37 \pm 0.02^{\mathrm{de}}$ & $60.26 \pm 1.91^{\mathrm{b}}$ \\
\hline 7 & $9.01 \pm 1.78^{\text {cdef }}$ & $1.32 \pm 0.03^{\mathrm{ef}}$ & $46.03 \pm 0.72^{\mathrm{d}}$ \\
\hline 8 & $7.02 \pm 1.65^{\text {fghi }}$ & $1.02 \pm 0.02^{\mathrm{g}}$ & $37.75 \pm 4.06^{e}$ \\
\hline 9 & $9.63 \pm 0.84^{\text {bcdef }}$ & $1.79 \pm 0.03^{b}$ & $52.26 \pm 1.32^{\mathrm{cd}}$ \\
\hline 10 & $10.77 \pm 3.08^{\mathrm{abc}}$ & $1.75 \pm 0.03^{\mathrm{b}}$ & $61.75 \pm 2.16^{\mathrm{ab}}$ \\
\hline 11 & $11.28 \pm 0.73^{\mathrm{abc}}$ & $1.53 \pm 0.04^{c}$ & $46.32 \pm 8.12^{\mathrm{d}}$ \\
\hline 12 & $11.17 \pm 0.95^{\mathrm{abc}}$ & $1.43 \pm 0.04^{\mathrm{d}}$ & $51.04 \pm 1.88^{\text {cd }}$ \\
\hline 13 & $7.37 \pm 0.32^{\text {efghi }}$ & $0.66 \pm 0.01^{\mathrm{ij}}$ & $32.99 \pm 2.61^{\mathrm{ef}}$ \\
\hline 14 & $8.73 \pm 1.78^{\text {cdefgh }}$ & $1.57 \pm 0.05^{c}$ & $60.19 \pm 4.78^{\mathrm{b}}$ \\
\hline 15 & $9.96 \pm 0.15^{\text {bcde }}$ & $1.24 \pm 0.12^{\mathrm{f}}$ & $5036 \pm 0.17^{c d}$ \\
\hline 16 & $12.47 \pm 0.719^{\mathrm{ab}}$ & $1.89 \pm 0.06^{a}$ & $56.62 \pm 3.69^{\mathrm{bc}}$ \\
\hline 17 & $7.77 \pm 0.83^{\text {defgh }}$ & $0.61 \pm 0.03^{j}$ & $47.74 \pm 2.60^{\mathrm{d}}$ \\
\hline 18 & $6.07 \pm 0.55^{\text {ghij }}$ & $0.57 \pm 0.01^{\mathrm{j}}$ & $25.69 \pm 1.13^{\mathrm{g}}$ \\
\hline 19 & $4.25 \pm 0.42^{\mathrm{j}}$ & $0.71 \pm 0.09^{i}$ & $21.08 \pm 0.34^{\mathrm{g}}$ \\
\hline 20 & $12.88 \pm 0.79^{a}$ & $1.72 \pm 0.16^{b}$ & $67.31 \pm 5.01^{\mathrm{a}}$ \\
\hline
\end{tabular}

Data given as mean \pm standard deviation of triplicate test. Data followed by the same letter are not significantly different according to Duncan's multiple comparison test. $\mathrm{P}=0.01$
(1:9) gave the highest total phenolic contents. Total flavonoid of 20 run order extracts and its were expressed as microgram quercetin/gram extract. The amount of total flavonoid contents ranged from 21.08 to $67.31 \mu \mathrm{g}$ quercetin/g extract (Table 2). The highest total flavonoid contents in $80 \%$ ethanol extract was extracted for 24 hours with ratio sample:solvent (1:9).

The radical scavenging activity was determined by DPPH radicals and ABTS radicals, which are commonly used for assessment of radical scavenging activity in vitro and results are given in Table 3 . All run order exhibited significant and dose dependent radical scavenging activity against both radicals. Measurement of antioxidant activity using DPPH method is expressed as \% inhibition values of $X$. granatum stem extract at a concentration of $100 \mathrm{ppm}$. The \% inhibition DPPH ranged from 17.40 to $70.92 \%$ (Table 3 ). The concentration of solvent with $40 \%$ ethanol, extraction time 8 hours, and ratio sample:solvent (1:6) has the highest activity among all samples, although the activity is not as high as ascorbic acid as positive control (Table 3 ).

The ability of the antioxidant activity of the ABTS method is reported by TEAC (Trolox Equivalent Antioxidant Capacity). The ABTS reducing property is directly proportional to the amount of phenolics, therefore, the potent ABTS reduction observed in this assay might be due to the phenolics and flavonoids

Table 3. Antioxidant and antiglycation activity of $X$. granatum stem extracts

\begin{tabular}{|c|c|c|c|}
\hline $\begin{array}{l}\text { Run } \\
\text { order }\end{array}$ & $\begin{array}{c}\% \\
\text { Inhibition } \\
\text { DPPH (\%) }\end{array}$ & $\begin{array}{c}\% \\
\text { Inhibition ABTS } \\
\text { (TEAC) }\end{array}$ & $\begin{array}{c}\text { \% Inhibition } \\
\text { antiglycation } \\
\text { (\%) }\end{array}$ \\
\hline 1 & $17.40 \pm 2.87^{j}$ & $0.21 \pm 0.010^{\mathrm{j}}$ & $78.66 \pm 22.79^{\text {cde }}$ \\
\hline 2 & $26.02 \pm 4.67^{\mathrm{ij}}$ & $0.27 \pm 0.021^{\mathrm{i}}$ & $73.62 \pm 7.70^{\text {de }}$ \\
\hline 3 & $57.25 \pm 15.57^{\mathrm{b}}$ & $0.37 \pm 0.001^{\mathrm{g}}$ & $102.48 \pm 29.03^{a}$ \\
\hline 4 & $70.92 \pm 3.38^{\mathrm{a}}$ & $0.38 \pm 0.001^{g}$ & $84.94 \pm 3.41^{\text {cde }}$ \\
\hline 5 & $55.26 \pm 0.94^{\mathrm{bc}}$ & $0.27 \pm 0.005^{\mathrm{i}}$ & $84.11 \pm 6.48^{\text {cde }}$ \\
\hline 6 & $50.13 \pm 3.69$ bcde & $0.57 \pm 0.001^{c}$ & $74.53 \pm 1.74 \mathrm{de}$ \\
\hline 7 & $36.87 \pm 7.91^{\text {ghi }}$ & $0.50 \pm 0.001^{\mathrm{e}}$ & $78.38 \pm 4.38^{\text {cde }}$ \\
\hline 8 & $51.28 \pm 4.68^{\mathrm{bcd}}$ & $0.39 \pm 0.001^{g}$ & $99.35 \pm 6.04^{\text {bcd }}$ \\
\hline 9 & $54.92 \pm 9.18^{\mathrm{bc}}$ & $0.54 \pm 0.001^{\mathrm{d}}$ & $131.66 \pm 3.04^{\mathrm{a}}$ \\
\hline 10 & $42.92 \pm 9.18^{\mathrm{defg}}$ & $0.59 \pm 0.003^{\mathrm{bc}}$ & $83.12 \pm 3.52^{\text {cde }}$ \\
\hline 11 & $28.72 \pm 6.01^{\mathrm{hi}}$ & $0.61 \pm 0.017^{\mathrm{b}}$ & $97.70 \pm 31.29 \mathrm{bcd}$ \\
\hline 12 & $31.78 \pm 8.67^{\text {ghi }}$ & $0.60 \pm 0.031^{\mathrm{b}}$ & $80.52 \pm 11.17^{\text {cde }}$ \\
\hline 13 & $41.94 \pm 1.85^{\text {defg }}$ & $0.39 \pm 0.020^{\mathrm{g}}$ & $77.96 \pm 4.53^{\mathrm{de}}$ \\
\hline 14 & $43.16 \pm 0.53^{\text {defg }}$ & $0.48 \pm 0.002^{\mathrm{e}}$ & $120.72 \pm 17.44^{\mathrm{ab}}$ \\
\hline 15 & $37.38 \pm 6.29^{\text {fghi }}$ & $0.53 \pm 0.027^{d}$ & $72.82 \pm 9.13^{\mathrm{de}}$ \\
\hline 16 & $32.88 \pm 3.32^{\text {ghi }}$ & $0.69 \pm 0.001^{\mathrm{a}}$ & $101.55 \pm 27.60^{\mathrm{abcd}}$ \\
\hline 17 & $41.94 \pm 1.21^{\text {defg }}$ & $0.42 \pm 0.002^{\mathrm{f}}$ & $55.11 \pm 9.07^{e}$ \\
\hline 18 & $37.18 \pm 2.33$ fghi & $0.32 \pm 0.004^{\mathrm{g}}$ & $56.34 \pm 11.37 \mathrm{e}$ \\
\hline 19 & $39.17 \pm 8.69^{\text {efgh }}$ & $0.23 \pm 0.001^{\mathrm{i}}$ & $99.28 \pm 17.52^{\mathrm{bcd}}$ \\
\hline 20 & $45.46 \pm 1.93^{\text {cdef }}$ & $0.70 \pm 0.001^{\mathrm{a}}$ & $110.59 \pm 33.56^{\mathrm{abc}}$ \\
\hline $\begin{array}{l}\text { Ascorbic } \\
\text { acid }\end{array}$ & $83.65 \pm 0.40$ & & \\
\hline
\end{tabular}

Data given as mean \pm standard deviation of triplicate test. Data followed by the same letter are not significantly different according to Duncan's multiple comparison test. $\mathrm{P}=0.01$ 
compounds present in extract. The TEAC of ABTS is ranged from 0.21 to 0.70 TEAC (Table 3 ). The highest TEAC value is found in the extract that macerated with $80 \%$ ethanol for 24 hours with a ratio of sample weight:solvent volume (1:9).

Antiglycation activity of 20 run order $X$. granatum stem extracts is given in Table 3. It showed that the glycation inhibition of all extract is more than 50\% (ranged from 55.11 to $120.72 \%$ at $100 \mathrm{ppm}$ concentration of extract). The highest \% inhibition of extracts was at run order no 14 , which was extraction with $80 \%$ ethanol, ratio sample:solvent (1:6), and extraction time 16 hours.

In the light with variance analysis result, it can be said that the triple interaction of yield, concentration solvent, and extraction time is found to be the most significant to yield of extraction. The response surface of this interaction is given in Figure 1. Figure 1a shows that maximum level of yield found between 25 and $50 \%$ of ethanol concentration and between 15 and 20 hours of extraction time. Figure $1 \mathrm{~b}$ and $\mathrm{c}$ shows that high level of the yield found between 25 and 50\% ethanol and between 20 and 25 hours of extraction time. The optimum conditions of three factors for all responds can be seen in Table 4 . The optimum conditions for each response are different, so to accommodate all responses, a point combination is drawn to describes the ideal conditions of all responses. The optimum extraction condition to produce the highest response was predicted by the model at $52.25 \%$ concentration, extraction time for 15.92 hours, and sample/solvent ratio of $1 \mathrm{~g} / 9 \mathrm{ml}$. The optimum condition is expected to produce all responds as shown in Table 4.

Validation of the optimum conditions is performed by evaluate the responds of extract that produced in optimum condition. The results showed that the response value is not significantly different with predicted as shown in Table 4.

\section{Discussion}

The phenolic content of 20 run order extracts gave the highest content at ethanol $40 \%$ extract. It means that phenolic is effectively extracted with combination of ethanol and water. With this concentration of ethanol

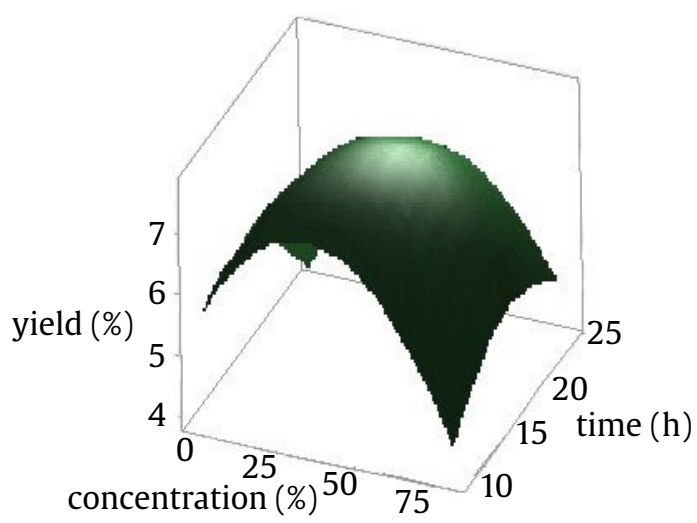

a

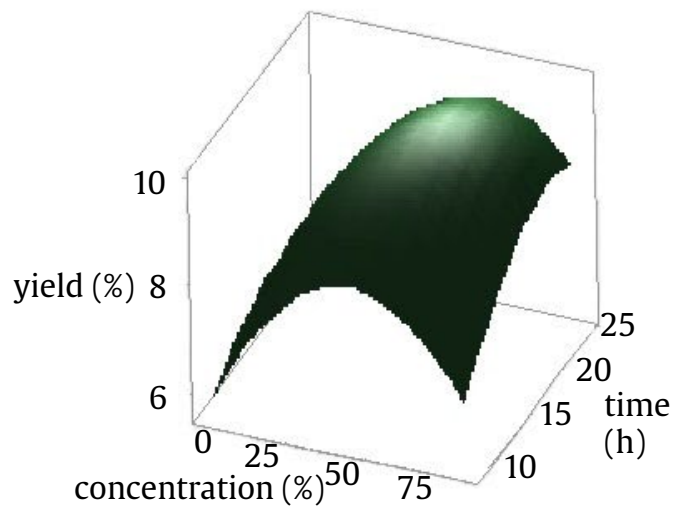

b

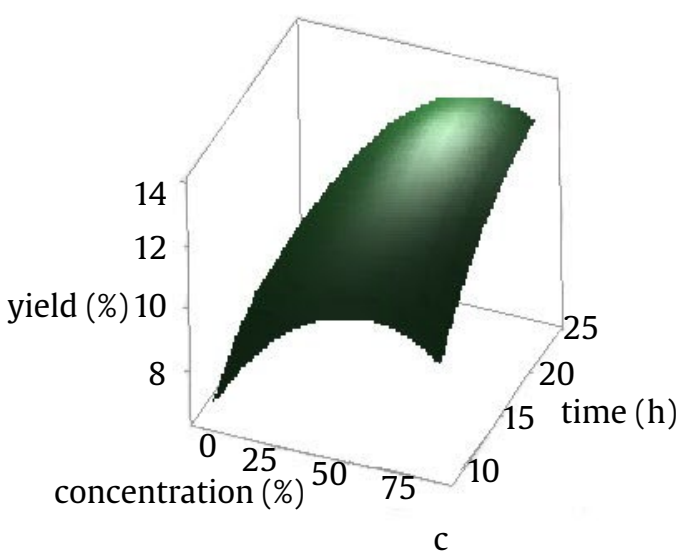

Figure 1. The responds surface of triple interaction of yield (\%), concentration of ethanol (\%), and extraction time (h) with ratio of sample to solvent of 1:3 (a), 1:6(b), and 1:9(c) 
Table 4. Prediction and validation test results for $X$. granatum stem extracts

\begin{tabular}{lll}
\hline Respons & \multicolumn{1}{c}{ Predicted } & \multicolumn{1}{c}{ Validation } \\
\hline Yields & $12.81 \%$ & $15.27 \%$ \\
Total phenolic & $\begin{array}{c}1.95 \mu \text { mg gallic acid/g } \\
\text { extract }\end{array}$ & $\begin{array}{c}1.13 ~ \mathrm{mg} \text { gallic acid/g } \\
\text { extract }\end{array}$ \\
Total flavonoid & $\begin{array}{c}62.33 \mu \mathrm{g} \text { quercetin/g } \\
\text { extract }\end{array}$ & $\begin{array}{c}56.73 \mu \mathrm{g} \text { quercetin/g } \\
\text { extract }\end{array}$ \\
DPPH & $44.11 \%$ & $44.76 \%$ \\
ABTS & $0.71 \mathrm{TEAC}$ & $0.54 \mathrm{TEAC}$ \\
Antiglycation & $112.33 \%$ & $116.05 \%$ \\
\hline
\end{tabular}

as solvent for extraction, plant cell wall will easier to degrade and phenolic compounds will be easier to get out of plant cells (Tiwari et al. 2011). Flavonoid is one group of phenolic compounds that widely distributed in plant parts such as leaves, seeds, bark, and flowers and can act to scavenging the reactive oxygen species. Therefore, they generally possess as a good antioxidant and their effects on human nutrition and health are considerable (Orhan et al. 2007). According to Chang et al. (2009) X. granatum is a species contains flavonoid compound which are potent as antioxidant.

The antioxidant potential of medicinal plants is due to the redox properties of phenolic compounds, which enable them to act as reducing agents, hydrogen donors and singlet oxygen scavengers (Moyo et al. 2010). It means that antioxidant activity from plants is closely related to the total content of phenolic and flavonoids (Naik et al. 2003). However, antioxidant capacity does not always positively correlate with total phenolic content (Scalzo et al. 2005). DPPH and ABTS both are radical agent but had a slight difference in the results. It because they have different types of free radicals and sensitivity (Shalaby and Shanab 2013; Zahra et al. 2016).

Phenolic compounds are also play an important role in the process of anti-glycation that lead to inhibit aging process, because its ability to reduce free radicals (Suwannalert et al. 2012; Sharafzadeh 2013). Antioxidants can inhibit the formation of AGEs. However, the anti-glycation activity does not always positively correlate with antioxidant activity, because both activities have different mechanism reactions. Our results revealed a strong positive correlation of antiglycation with total flavonoid contents and ABTS radical scavenging of $X$. granatum stem extract, especially at run order of 20 . Findings of their study support the evidence that phenolic compounds significantly inhibit the protein glycation (Peng et al. 2008).
Validation results were found to be very close to the prediction. This modeling provides information that extraction can be carried out with a short time extraction, optimum solvent concentrations, and optimum ratio of sample and solvent. Variable solvent concentration, extraction time, and ratio sample:solvent had significant effect on yield, total phenolic contents, DPPH and ABTS methods antioxidant activity, and antiglycation activity. The optimum extraction conditions obtained were ethanol concentration as solvent of extraction $52.25 \%$, ratio sample:solvent (1 g:9 ml), and extraction time for 15.92 hours. This optimum condition will reduce the processing time (extraction time), produce high yield of extraction with high bioactive constituent, and will reduce production cost especially extraction cost.

\section{Acknowledgements}

This work was supported by the Ministry of Research, Technology, and Higher Education Republic of Indonesia on Penelitian Dasar (Kerjasama Luar Negeri dan Publikasi Internasional) contract no 4109/IT3.L1/PN/2019.

\section{Reference}

Bandaranayake WM. 2002. Bioactivities, bioactive compounds and chemical constituents of mangrove plants. Wetland Ecology Mangrove 10:421-452.

Batubara I et al. 2010. Potency of Indonesian medicinal plants as tyrosinase inhibitors and antioxidant agent. Journal of Biological Sciences 10:138-144.

Batubara I, Adfa M. 2013. Potensi daun kayu bawang (Protium javanicum) sebagai penghambat kerja enzim tirosinase. Journal of Mathematical Science 1:52-56.

Batubara I et al. 2015. Flower bracts of temulawak (Curcuma xanthorrhiza) for skin care: anti-acne and whitening agents. Procedia chemistry 14:216-224.

Bernatoniene J et al. 2011. Topical application of Calendula officinalis $(\mathrm{L})$; formulation and evaluation of hydrophilic with antioxidant activity. Journal of Medicinal Plant Research 5:868-877.

Chang CC et al. 2009. Estimation of total flavonoid content in propolis by two complementary colorimetric methods. Journal of Food and Drug Analysis 10:178-182.

Chen PN et al. 2006. Black rice anthocyanins inhibit cancer cells invasion via repressions of MMPs and uPA expression. Chemico-Biol 29:219-224.

Darusman LK et al. 2011. Screening marker components of tyrosinase inhibitor from Xylocarpus granatum stem. Valensi 2:409-413.

Gazali M et al. 2014. Potensi limbah kulit buah nyirih Xylocarpus granatum sebagai inhibitor tirosinase. Jurnal Ilmu-Ilmu Perairan, Pesisir, dan Perikanan 3:187-194. 
Halliwell B. 2001. Role of free radicals in the neurodegenerative diseases: therapeutic implications for antioxidant treatment. Drugs and Aging 18:685-716.

Kopkol V et al. 1990. Chemical constitutents and bioactive compounds from mangrove plants. Studies in Natural Products Chemistry 7:175-199.

Lee SH et al. 2011. Acetylchlolinesteraceae inhibitory and antioxidant properties of Rhododendron yedoense var. Poulhanense bark. Journal of Medicinal Plants Research 5:248-254.

Moyo M et al. 2010. Phenolic composition, antioxidant and acetycholinesterase inhibitory activities of Sclerocarya birrea and Harpephyllum caffrum (Anacrdiaceae) extracts. Food Chem 123:69-76.

Naik GH et al. 2003. Comparative antioxidant activity of individual herbal components used in ayurvedic medicine. Phytochemistry 63:97-104.

Orhan I et al. 2007. Screening of various phenolics acids and flavonoid derivatives for their anticholinesterase potential. Z Naturforsch 62:829-832.

Peng X et al. 2008. Inhibitory effect of mung bean extract and its constituents vitexin and isovitexin on the advanced glyction endproducts. Food Chem 106:475-481.

Povichit GV et al. 2010. Phenolic content and in vitro inhibitory effects on oxidation and protein glycation of some Thai medicinal plants. Pakistan Journal of Pharmaceutical Science 23:403-408.

Premakumara et al. 2013. Antioxidant, anti-amylase and anti-glycation potential of brans of some Sri Lankan Traditional and improved rice (Oryza sativa L) varieties. Journal of Cereal Science 58:451-456.

Rabbani N et al. 2016. Dicarbonyls and glyoxalase in disease mechanisms and clinical therapeutics. Glycoconjugate Journal 33:513-525.

Ree R et al. 1999. Antioxidant activity applying an improved ABTS radical cation decolorization assay. Free Radical Biology and Medicine 26:1231-1237.
Scalzo J et al. 2005. Plant genotype affects total antioxidant capacity and phenolic contents in fruit. Journal of Nutrition 21:207-213.

Shalaby EA, Shanab SMM. 2013. Antioxidant compounds, assays of determination and mode of action. African Journal Pharmacy and Pharmacology 7:528-539.

Sharafzadeh S. 2013. Medical plants as anti-aging materials: a review. Global Journal of Medicinal Plants Research $1: 234-236$.

Suwannalert P et al. 2012. The levels of lycopene, alphatocopherol and a marker of oxidative stress. Asia Pacific Journal of Clinical Nutrition 16:27-30.

Thornfeldt C, Bourne K. 2010. The New Ideal in Skin Healt: Separating Factfrom Fiction Practical Application of the Science of Skin Care. California: Allured Business Media Carol Stream.

Tiwari P et al. 2011. Phytochemical screening and extraction: a review. Internationale Pharmaceutica Sciencia 1:98-106.

Yagi S et al. 2013. Antioxidan and antiglycation properties of Hydnora johannis roots. South African Journal of Botany 84:124-127.

Yeh W et al. 2017. Polyphenols with antiglycation activity and mechanisms of action: A review of recent findings. Journal of Food and Drug Analysis 25:84-92.

Zahra U et al. 2016. Screening the potency of Zingiberaceae leaves as antioxidant and antiaging agent. Nusantara Bioscience 8:221-225.

Zamani NP et al. 2015. The study of tyrosinase and antioxidant activity of Xylocarpus granatum koenig seed kernel extract toward evidence based indigenous knowledge from Togean Archipelago Indonesia.J Marine Sci Res Dev 5:168-172. 